\title{
Prevalence of oral manifestations in soft tissues during early childhood in Brazilian children
}

\section{Maria Cristina Ramos Lima PADOVANI(a) \\ Maria Teresa Botti Rodrigues \\ SANTOS ${ }^{(b)}$ \\ Giselle Rodrigues de \\ SANT'ANNA(a) \\ Renata Oliveira GUARÉ(a)}

(a) Department Pediatric Dentistry, School of Dentistry, Universidade Cruzeiro do Sul UNICSUL, São Paulo, SP, Brazil.

(b)Special Needs Individuals, School of Dentistry, Universidade Cruzeiro do Sul UNICSUL, São Paulo, SP, Brazil.

Declaration of Interests: The authors certify that they have no commercial or associative interest that represents a conflict of interest in connection with the manuscript.

Corresponding Author:

Maria Cristina Ramos Lima Padovani Email: cristina.r.padovani@hotmail.com

DOI: 10.1590/1807-3107BOR-2014.vol28.0036 Epub XXXXX, 2014

Submitted: May 09, 2013

Accepted for publication: May 06, 2014

Last revision: Jul 23, 2014

\begin{abstract}
This study aimed at assessing the prevalence of soft tissue oral manifestations in children during early childhood, according to age group, gender, and site in the oral cavity, and at correlating these oral manifestations with systemic alterations. A cross-sectional study was conducted involving 586 children from 0 to 3 years of age (12.4 \pm 11.8 months), 316 (53.9\%) male and 270 (46.1\%) female, in the city of Mauá, SP, Brazil. Examination was performed by a single examiner (Kappa Index $=0.90)$ according to World Health Organization criteria (WHO, 1997).The prevalence of oral manifestations in the soft tissues of children during early childhood was $34.8 \%$. The age group showing statistical significance was $0-1$ months old (56.4\%). Epstein's pearls were significantly present (43.2\%) in 0-1-monthold babies, and gingivitis in 12-24-month-olds (15.9\%). The palate was the most affected region (16.7\%). Infectious alterations were the most prevalent systemic alteration (20\%). An association was observed between the presence of systemic alterations and the occurrence of oral manifestations. The prevalence of oral manifestations was $34.8 \%$, regardless of gender, and was manifested mostly in 0-1-month-old babies. The palate was the most prevalent region, and the majority of oral manifestations were associated with systemic alterations.
\end{abstract}

Keywords: Child; Diagnosis, Oral; Pathology; Prevalence.

\section{Introduction}

In order to achieve and maintain oral health during early childhood, it is important for the pediatric dentist to know how to diagnose and treat oral manifestations, whenever necessary. A baby presents unique and transitional anatomical structures that are typical of this age of life. Aside from the characteristic physiological alterations occurring in this age group, there are specific developmental alterations and diseases. ${ }^{1,2,3,4}$

Numerous studies have proven the importance of the dentist during the diagnostic process of many systemic diseases. The first manifestation of systemic alterations often occurs in the oral cavity. ${ }^{5,6}$

There are many reports in the literature regarding dental caries ${ }^{7,8}$ and periodontal disease; ${ }^{9,10}$ however, there are few studies related to the prevalence of soft tissue manifestations, and they address varied methodological criteria. The effort being made to offer an appropriate system for collecting data is insufficient, resulting in a series of methodological problems that often yield incorrect and inconsistent results. Epidemiological studies conducted in 
the past have shown a considerable discrepancy in the prevalence of soft tissue lesions in the oral cavity. 11,12,13,14

The purpose of this study was to assess the prevalence of oral manifestations in the soft tissues of Brazilian children from 0 to 36 months old, according to age group, gender, and location, and to correlate these manifestations with the presence of systemic alterations.

\section{Methodology}

This cross-sectional survey was first conducted with a sample composed of 706 children treated at the Unidade de Saúde (Municipal Health Unit -HU) of Mauá, State of São Paulo, Brazil, from May to December 2007, following approval by the Research Ethics Committee (EC/CSU072/06).The inclusion criteria were children from 0 to 36 months old, of both genders and all ethnicities. The exclusion criteria were children with nasal/labial cleft, children undergoing dental restorative treatment who were not participating in the orientation groups, children with dental urgencies, and children whose legal guardians did not agree to sign the consent term. The final sample resulted in 586 children ( $12.4 \pm 11.8$ months), 316 (53.9\%) male and 270 (46.1\%) female. Diagnosis of systemic alterations was determined by a pediatrician.

The clinical examination of babies under 12 months old was conducted in the knee-to-knee position, under the operating light of the dental chair, whereas the remaining children were examined in the dental chair. In the maternity ward, the procedure was conducted in the maternity crib, using a penlight. The examination was conducted by a single, previously trained examiner (Kappa $=0.90)$. The spreadsheet data from the epidemiological survey and the photos of the oral manifestations, duly authorized by the legal guardians, were collected by the HU dental nurse, and the data from the maternity were collected by the neonatal nurse.

The WHO clinical diagnostic criteria were used to determine oral mucosal alterations, ${ }^{15,16}$ as used by other authors. ${ }^{12,17,18}$ The sequence of examinations of the oral mucosa includes: 1- upper lip (vermilion); 2- upper labial mucosa; 3- upper alveolar mucosa; 4- upper gingival/alveolar ridge; 5 - hard palate; 6soft palate; 7- oropharynx; 8- dorsum of the tongue; 10- ventral tongue; 11 - floor of the mouth; 12 , lower gingival/alveolar ridge; 13 - lower alveolar mucosa; 14- right and left buccal mucosa; 15- lower labial mucosa; 16- lower lip (vermillion); and 17- labial commissures.

For data analysis purposes, the 586 children examined were divided into 4 groups according to age: 0 to 1 month old (34\%), 1 to 12 months old (19\%), 12 to 24 months old (24.8\%) and 24 to 36 months old (22.2\%). The criteria for dividing the sample into age groups were based on major changes in the oral cavity and the appearance of oral manifestations: 0-1 months, newborn; 1-12 months, a period of neurophysiologic changes and feeding accompanied by tooth eruption; 12-24 months, eruption of primary molars; $24-36$ months, a period in which the primary dentition is complete and stable.

Age groups, gender, oral manifestations and systemic conditions were compared using the Chi square and Fisher Exact tests (Minitab statistic software, version 14.2, Minitab Inc., State College, USA), together with a binary logistic regression model to identify predictors of oral manifestations, considered as independent variables (PASW Statistics v. 18.0.0, SPSS Inc., Chicago, USA).

All the tests were analyzed with a significance of $p<0.05$.

\section{Results}

The oral manifestation distribution according to age and gender (Table 1) showed a statistically significant difference related to age. In the first month of life, a higher percentage of oral manifestations are observed, probably related to inclusion cysts.

Table 1. Distribution of oral manifestation cases according to age and gender.

\begin{tabular}{|c|c|c|c|c|}
\hline & \multicolumn{2}{|c|}{ Oral Manifestation } & \multirow[b]{2}{*}{$\begin{array}{l}\text { Total } \\
N(\%)\end{array}$} & \multirow[b]{2}{*}{$p$} \\
\hline & $\begin{array}{l}\text { Yes } \\
N(\%)\end{array}$ & $\begin{array}{c}\text { No } \\
N(\%)\end{array}$ & & \\
\hline \multicolumn{5}{|l|}{ Age group } \\
\hline $0 \varnothing 1$ month & $111(56.4)$ & $86(43.6)$ & 197 (100) & $<0.001$ \\
\hline $\begin{array}{l}1 \varnothing 12 \\
\text { months }\end{array}$ & $18(15.8)$ & $96(84.2)$ & $114(100)$ & \\
\hline $\begin{array}{l}12 \varnothing 24 \\
\text { months }\end{array}$ & $53(36.6)$ & $92(63.4)$ & $145(100)$ & \\
\hline $\begin{array}{l}24 \varnothing 36 \\
\text { months }\end{array}$ & $22(16.9)$ & $108(83.1)$ & $130(100)$ & \\
\hline \multicolumn{5}{|l|}{ Gender } \\
\hline male & $108(34.2)$ & $208(65.8)$ & $316(100)$ & 0.727 \\
\hline female & $96(35.6)$ & $174(64.4)$ & $270(100)$ & \\
\hline Total & $204(34.8)$ & $382(65.2)$ & $586(100)$ & \\
\hline
\end{tabular}

Chi square test $(p<0.05)$. 
Table 2. Prevalence of oral manifestations according to age group.

\begin{tabular}{|c|c|c|c|c|c|c|}
\hline \multirow[b]{2}{*}{ Oral manifestation } & \multicolumn{4}{|c|}{ Age group (months) } & \multirow[b]{2}{*}{$\begin{array}{l}\text { Total } \\
\text { N (\%) }\end{array}$} & \multirow[b]{2}{*}{$p^{*}$} \\
\hline & $\begin{array}{l}0 \varnothing 1 \\
N(\%)\end{array}$ & $\begin{array}{l}1 \varnothing 12 \\
N(\%)\end{array}$ & $\begin{array}{c}12 \varnothing 24 \\
N(\%)\end{array}$ & $\begin{array}{c}24 \varnothing 36 \\
N(\%)\end{array}$ & & \\
\hline Epstein's pearls & $85(43.2)$ & $2(1.8)$ & - & - & $87(14.8)$ & $<0.001$ \\
\hline gingivitis & $2(1.0)$ & $3(2.7)$ & $23(15.9)$ & $12(9.2)$ & $40(6.8)$ & $<0.001$ \\
\hline ankyloglossia & $13(6.6)$ & $5(4.4)$ & $4(2.8)$ & $2(1.5)$ & $24(4.1)$ & 0.024 \\
\hline Bohn's nodules & $20(10.2)$ & $4(3.5)$ & - & - & $24(4.1)$ & $<0.001$ \\
\hline eruption gingivitis & $1(0.5)$ & - & $15(10.3)$ & $4(3.1)$ & $20(3.4)$ & $<0.001$ \\
\hline dental lamina cyst & $11(5.6)$ & - & - & - & $11(1.9)$ & - \\
\hline candidiasis & $2(1.0)$ & $6(5.3)$ & $1(0.7)$ & - & $9(1.5)$ & - \\
\hline eruption cyst & $2(1.0)$ & - & $5(3.5)$ & $1(0.8)$ & $8(1.4)$ & - \\
\hline primary herpes & - & - & $3(2.1)$ & $1(0.8)$ & $4(0.7)$ & - \\
\hline traumatic lesions & - & - & $2(1.4)$ & $2(1.5)$ & $4(0.7)$ & - \\
\hline geographic tongue & - & - & $3(2.1)$ & $1(0.8)$ & $4(0.7)$ & - \\
\hline coated tongue & $3(1.5)$ & - & $1(0.7)$ & - & $4(0.7)$ & - \\
\hline molluscum contagiosum & - & - & - & $2(1.5)$ & $2(0.3)$ & - \\
\hline eruption hematoma & - & $1(0.9)$ & $1(0.7)$ & - & $2(0.3)$ & - \\
\hline persistent frenum labialis & - & - & - & $2(1.5)$ & $2(0.3)$ & - \\
\hline angular cheilitis & - & - & $1(0.7)$ & - & $1(0.2)$ & - \\
\hline aphthous ulcer & - & $1(0.9)$ & - & - & $1(0.2)$ & - \\
\hline total of patients & $197(100)$ & $113(100)$ & $145(100)$ & $131(100)$ & $586(100)$ & - \\
\hline
\end{tabular}

* Chi square test $(p<0.05)$.

Accordingly, Epstein's pearls (a subtype of inclusion cysts) were more prevalent in the first month of life (Table 2), insofar as they are typical of this age group. However, gingivitis was prevalent in the age group of 12-24 months, the period of tooth eruption.

Inclusion cysts are frequently found in the oral cavities of newborn infants and are sub-grouped according to their location (alveolar or palatal) and origin. Epstein's pearls are cystic, keratin-filled nodules observed along the mid palatine raphe, derived from entrapped epithelial remnants. Bohn's nodules are mucous-gland cysts, on the alveolar ridges in the vestibular and lingual surfaces. Dental lamina cysts are observed on top of the alveolar ridge of newborns, originating from remnants of the dental lamina., ${ }^{4,19}$

No significant difference in the prevalence of oral manifestations was observed related to the child's sex.

Concerning the region of the manifestations, the palate presented the most oral manifestations (16.7\%), followed by gingiva (11.4\%), alveolar ridge $(8.9 \%)$ and tongue $(7.8 \%)$.

The oral manifestation distribution, according to the systemic alterations, is presented in Table 3, and the prevalence of systemic alterations, according to the oral manifestation, in Table 4.
Table 5 shows the results for the logistic regression, together with the odds ratio values for each variable, in relation to oral manifestations. The results of this regression established an independent association between age group (1-12 months, 12-24 months, and 24-36 months), systemic change and oral manifestations. Children aged 1-12 months, 12-24 months and 24-36 months were $8.2 \%, 30.4 \%$ and $11.3 \%$ more likely, respectively, to present oral manifestations than babies between 0-1 months. Furthermore, children who presented systemic changes showed a 17.4-fold greater risk of exhibiting oral manifestations, compared with children who presented no systemic change. The inclusion of all these variables in the model, including gender, did not effect any change in the associations between oral manifestations, systemic changes and age group identified in the univariate analyses.

Table 3. Distribution of oral manifestations according to cases of systemic alterations.

\begin{tabular}{lcccc}
\hline & \multicolumn{2}{c}{ Oral manifestation } & & \\
\cline { 2 - 4 } Systemic & Yes & No & Total & \\
alterations & $N(\%)$ & $N(\%)$ & $N(\%)$ & $p$ \\
\hline Yes & $57(85.1)$ & $10(14.9)$ & $67(100)$ & \\
No & $147(28.3)$ & $372(71.7)$ & $519(100)$ & $<0.001$ \\
Total & $204(34.8)$ & $382(65.2)$ & $586(100)$ & \\
\hline Chi square test $(p<0.05)$. & & &
\end{tabular}


Table 4. Prevalence of systemic alterations according to cases of oral manifestation.

\begin{tabular}{lccc}
\hline Systemic alterations & \multicolumn{3}{c}{ Oral manifestation } \\
\cline { 2 - 4 } & Yes & No & Total \\
& N & N & N (\%) \\
\hline Infectious alterations & 20 & - & $20(30.0)$ \\
Hematological alterations & 14 & 3 & $17(25.3)$ \\
Respiratory alterations & 11 & 6 & $17(25.3)$ \\
Congenital alterations & 9 & - & $9(13.4)$ \\
Gastrointestinal & 3 & 1 & $4(6.0)$ \\
alterations & & & \\
Total number of patients & 57 & 10 & $67(100)$ \\
\hline Fisher Exact
\end{tabular}

Fisher Exact test $(p<0.05)$

Table 5. Results of the logistic regression using oral manifestations as the dependent variable and the other variables as independent variables.

\begin{tabular}{lcc}
\hline Variables & $\begin{array}{c}\text { Odds Ratio } \\
(95 \% \mathrm{Cl})\end{array}$ & $p$ value \\
\hline Systemic alterations & 17.426 & $<0.001$ \\
Sex (female) & $\begin{array}{c}.880-34.197 \\
1.044\end{array}$ & 0.833 \\
$1-12$ months & $0.700-1.556$ & \\
& 0.082 & $<0.001$ \\
12 - 24 months & $0.041-0.162$ & \\
& 0.304 & $<0.001$ \\
24 - 36 months & $0.186-0.497$ & \\
& 0.113 & $<0.001$ \\
\hline
\end{tabular}

\section{Discussion}

In order to achieve and maintain oral health during early childhood, it is important for the pediatric dentist to know how to diagnose and treat oral manifestations in this age group. This study helps identify the oral soft tissue manifestations that are more prevalent in early childhood, mainly related to systemic changes, and determine the appropriate approach. The prevalence of oral manifestations in the soft tissue of children, as found in our study, was very similar to that reported in other studies; however, studies involving the age group from 0 to 36 months old are uncommon. In Spain, ${ }^{20} 38.9 \%$ of 6 year-old children presented oral manifestations in soft tissues, whereas a prevalence of $32.9 \%$ was reported in 18 to 80 month-old children in South Africa. ${ }^{17}$ In Argentina, ${ }^{21} 33.8 \%$ of oral manifestations occurred in the age group from 0 to 15 years old, and 39\%, from 4 to 13 years old, whereas the frequency of children age 0 to 12 years presenting oral mucosal diseases was $28.4 \%$ in Italy. ${ }^{22}$
In other regions, an increase was observed in the prevalence of oral manifestations in soft tissues, from $52.57 \%$ in the age group from 0 to 12 years old ${ }^{23}$ to $24.9 \%$ in the age group from 0 to 4 years old. ${ }^{18}$ In Brazil, the age group from 0 to 24 months old ${ }^{19}$ showed a prevalence of $21 \%$ for oral manifestations, whereas the prevalence in the age group from 0 to 5 years old was $2.30 \% .{ }^{24}$ In other countries, the prevalence was $4 \%$ in the age group from 5 to 17 years old, ${ }^{12}$ compared with other studies, like NHANES III, where the prevalence for children from 2 to 17 years old was $9.11 \%{ }^{25}$

Among cystic manifestations, the most prevalent were newborn cysts, with $20.8 \%$ in the age group from 0 to 36 months old. In relation to newborn cysts (Epstein's pearls, Bohn's nodules and dental lamina cysts), Epstein's pearls were the manifestation with the highest prevalence (14.8\%). Similarly, Baldani et al. ${ }^{19}$ also observed that the newborn inclusion cysts (23.62\%) were more prevalent than the other cystic lesions.

Notably, some authors observed a higher prevalence of gingival cysts than that observed in this study. One such case was Flinck et al., ${ }^{4}$ who determined a prevalence of $74.9 \%$ for all the children assessed in the same age group from 0 to 1 month old. Corrêa et al. ${ }^{26}$ determined a prevalence rate of $42.9 \%$ in the age group from 0 to 1 month old, similar to the rate found in the present study; however, Baldani et al. ${ }^{19}$ verified gingival cysts in $7.5 \%$ of the children in the age group from 0 to 24 months old.

Among the infectious manifestations, chronic gingivitis was confirmed as the most prevalent $(6.8 \%)$ among all the children assessed, in that the most commonly affected age group was that of 12-to24-month-olds (10.3\%). However this manifestation was observed only in $1.5 \%$ of 0 to 24 -month-olds, ${ }^{19}$ and the most commonly affected age group was also that of 12-to-24-month-olds (2.86\%).

When considering candidiasis, $1.5 \%$ presented this infectious manifestation, in that the most commonly affected age group was 1-to-12-month-olds (5.3\%). Another study ${ }^{25}$ reported that $1.23 \%$ of the children assessed presented candidiasis in the age group from 0 to 7 years old. Candidiasis was slightly more prevalent among males $(1.9 \%)$ than females $(1.1 \%)$. Baldani et al ${ }^{19}$ reported candidiasis in $2.50 \%$ of the age group from 0 to 24 months old, and males were 
slightly more affected $(2.78 \%)$, similar to the results found in the present study. Crivelli et al. ${ }^{21}$ observed candidiasis at a frequency similar to that determined in the present study; however, Kleinman et al. ${ }^{12}$ determined a prevalence of only $0.01 \%$ in cases of children from 5 to 17 years of age. This is significantly lower than the percentage determined in the present study, although the age groups differed. The prevalence of candidiasis within a broad age group in some studies ranges from $12 \%{ }^{13}$ to $0.57 \% .^{24}$

It should be emphasized that few studies exist reporting or even including cases of molluscum contagiosum, a viral disease that affects the skin and mucosa of the entire body, with the exception of the palm of the hands and the sole of the feet. ${ }^{5,20,27,28}$ The present study observed that $0.3 \%$ of the children assessed presented this disease, in that the most affected age group was that of 24-to-36-month-olds $(1.5 \%)$, although no statistically significant differences were observed in regard to gender.

Regarding herpetic gingivostomatitis, the study revealed that, among all the children assessed, $0.7 \%$ presented this disease, in that the most affected age group was 12-to-24-month-olds (2.1\%). Santos et al. ${ }^{23}$ determined a $0.6 \%$ prevalence of primary herpes, whereas Bessa et al..$^{18}$ reported $0.4 \%$. With respect to this manifestation, males were slightly more affected $(1 \%)$. The absence of recurring lip herpes cases in this study can probably be attributed to the fact that the age group studied was very young. It is important to highlight that similar studies focused on different age groups, making direct comparison with the present study results difficult.

Among all the children examined, $4.1 \%$ presented ankyloglossia, and males were more frequently affected (5.4\%). Messner et al. ${ }^{29}$ observed a similar result of $4.8 \%$ cases among all the children assessed in the age group from 0 to 1 month old, whereas other authors reported a lower prevalence., ${ }^{4,11,19}$ Garcia-Pola et al. ${ }^{20}$ also reported that males were slightly more affected.

The present study observed that $0.7 \%$ of the total number of children assessed presented traumatic lesions, in that the most affected age groups were those 12 to 24 months old (1.4\%) and 24 to 36 months old $(1.5 \%)$. Similar results were observed in some studies, ${ }^{21}$ whereas a slightly higher prevalence was seen in others. ${ }^{13,17,18,23}$

In relation to all the types of non-traumatic lesions that affect the mucosa, aphthous ulceration was the most prevalent. ${ }^{30}$ In our study, $0.2 \%$ of all the children examined presented aphthous ulceration, in that the most affected age group was that of 1 to 12 months old $(0.9 \%)$, and males were the most affected $(0.3 \%)$. Similar results were observed in some studies, ${ }^{12,23}$ whereas the prevalence was higher in others, $11,13,20$ and, in one, females were slightly more affected than males. ${ }^{20}$

According to the literature, a wide range of terminology is used in relation to the data observed: lesions,,$^{2,6,11,13,17,20,22,25}$ diseases, ${ }^{14,16}$ abnormalites, ${ }^{1,26}$ oral findings ${ }^{4}$ conditions, ${ }^{16,23,24}$ oral pathologies, ${ }^{21}$ oral alterations, ${ }^{18}$ and oral changes. ${ }^{19}$ The term "oral manifestations" generally encompasses all of these classifications, and was used in this study.

Few epidemiological studies have correlated oral manifestations with systemic alterations. In the present research, 67 (11.4\%) of the 586 children assessed presented systemic alterations. Notably, a very strong association was observed between the existence of a systemic alteration and the occurrence of oral manifestations $(p<0.001)$. A large percentage of mucosal lesions were related to systemic changes (85.1\%), and were diagnosed following dental and medical evaluation, in contrast with another study, ${ }^{18}$ in which oral alterations were observed following the use of antibiotics. After diagnosis, specific prescriptions were given for systemic changes.

Immunosuppression (systemic alteration) predisposes a child to candidiasis, recurring aphthous ulceration, periodontal disease, herpes simplex and glandular alterations. ${ }^{22}$

Crivelli et al. ${ }^{11}$ and Arendorf and Vander Ross ${ }^{17}$ reported angular cheilitis in children of low socioeconomic conditions, resulting from malnutrition and folic acid, riboflavin and iron deficiencies. However, the research by Garcia-Pola et al. ${ }^{20}$ found that children of higher socioeconomic conditions also presented this alteration. In this research, the children's socioeconomic condition was not assessed, although all of the children used public healthcare services. 
The limitations of this study were that it was a convenience sample and had a cross-sectional design. Although based on the findings of the present study and those of other authors, it can be asserted that oral manifestations in newborns are not as rare as the sparse literature might suggest. However, it is necessary to standardize research methodologies, in order to enable the comparison and discussion of all the results obtained. Dental professionals who treat children in this age group must be able to diagnose and treat the oral manifestations whenever necessary, and to refer the child to a pediatrician for effective treatment, if the

\section{References}

1. Sedano HO, Carreon Freyre I, Garza de la Garza ML, Gomar Franco CM, Grimaldo Hernandez C, Hernandez Motoya ME, et al. Clinical orodental abnormalities in Mexican children. Oral Surg Oral Med Oral Pathol. 1989 Sep; 68(3):300-11.

2. Flaitz CM, Baker KA. Treatment approaches to common symptomatic oral lesion in children. Dent Clin North Am. 2000 Jul;44(3):671-96.

3. Mattos-Graner RO, Moraes AB, Rontani RMP, Birman EG. Relation of oral yeast infection in Brazilian infants and use of a pacifier. ASDC J Dent Child. 2001 Jan-Feb;68(1):33-6,10.

4. Flinck A, Paludan A, Matsson L, Holm AK, Axelsson I. Oral findings in a group of newborn Swedish children. Int J Paediatr Dent. 1994 Jun;4(2):67-73.

5. Pérez VMF, Mata M, Vielma H, Oliver M.[Molluscum contagiosum on lip unusual presentation: a case report]. Acta Odontol Venez. 2000 [cited Aug 10];38(3):36-8. Avaliable from: http://www.actaodontologica.com/ediciones/2000/3/ molusco_contagioso_labio.asp. Spanish.

6. Guerra ME, Tovar V, Garrido E, Carvajal A. [Oral lesions and immune status in children HIV/AIDS]. Acta Odontol Venez [Internet]. 2007 [cited Aug 10];45(2):225-8. Avaliable from: http://www.actaodontologica.com/ediciones/2007/2/ pdf/lesiones_bucales_estatus_inmunologico.pdf Spanish.

7. Maxim DC, Danila I, Dascalu CG, Balcos C. [Early childhood caries. Epidemiological considerations]. Rev Med Chir Soc Med Nat Iasi. 2010 Jul-Sep;114(3):866-9. Romanian.

8. Arora A, Scott JA, Bhole S, Do L, Schwarz E, Blinkhorn AS. Early childhood feeding practices and dental caries in preschool children: a multi-centre birth cohort study. BMC Public Health. 2011 Jan 12;11:28.

9. Foglio-Bonda PL, Gabriele M, Graziani F, De Andrea M, Mondini M, Gariglio M. High prevalence of human cytomegalovirus in a population of periodontally healthy subjects. Med Oral Patol Oral Cir Bucal. 2010 Mar 1;15(2):e292-6. presence of any systemic alteration is suspected. Thus, it is fundamental to understand the child in a holistic and dynamic manner, acknowledging the constant changes during his/her development and growth.

\section{Conclusions}

The prevalence of oral manifestations in the soft tissues of children during early childhood was $34.8 \%$, and could be associated with systemic alterations. Systemic alterations are indicators of risk of oral manifestations, and children aged 12 to 24 months old show a greater chance of presenting these oral manifestations.

10. Vidal F, Figueredo CM, Cordovil I, Fischer RG. Higher prevalence of periodontitis in patients with refractory arterial hypertension: a case-control study. Oral Dis. 2011 Sep;17(6):560-3.

11. Crivelli MR, Aguas S, Adler I, Quarracino C, Bazerque P. Influence of socioeconomic status on oral mucosa lesion prevalence in schoolchildren. Community Dent Oral Epidemiol. 1988 Feb;16(1):58-60.

12. Kleinman DV, Swango PA, Pindborg JJ. Epidemiology of oral mucosal lesions in United States schoolchildren: 198687. Community Dent Oral Epidemiol. 1994 Aug;22(4):243-53.

13. Haberland CM, Allen CM, Beck FM. Referral patterns, lesion prevalence, and patient care parameters in a clinical oral pathology practice. Oral Surg Oral Med Oral Pathol Oral Radiol Endod. 1999 May;87(5):583-8.

14. Rioboo-Crespo MR, Planells-del Pozo P, Rioboo-Garcia R. Epidemiology of the most common oral mucosal diseases in children. Med Oral Patol Oral Cir Bucal. 2005 NovDec;10(5):376-87.

15. World Health Organization. Oral health surveys: basics methods. $4^{\text {th }}$ ed. Geneva: WHO; 1997.

16. World Health Organization. Guide to epidemiology and diagnosis of oral mucosal diseases and conditions. Community Dent Oral Epidemiol. 1980 Feb;8(1):1-26.

17. Arendorf T, Van der Ross R. Oral soft tissue lesions in a black pre-school South African population. Community Dent Oral Epidemiol. 1996 Aug;24(4):296-7.

18. Bessa CFN, Santos BPJ, Aguiar MCF, Carmo MAV. Prevalence of oral mucosal alterations in children from 0 to 12 years old. J Oral Pathol Med. 2004 Jan;33(1):17-22.

19. Baldani MH, Lopes CML, Scheidt WA. Prevalence of oral changes in children attending public pediatric dental clinics in Ponta Grossa, PR, Brazil. Pesqui Odontol Bras. 2001 OctDec;15(4):302-7. Portuguese. 
20. Garcia Pola MJ, Garcia Martin J, Gonzáles-Garcia M. Prevalence of oral lesions in the 6-year-old pediatric population of Oviedo (Spain). Med Oral. 2002 May-Jun; 7(3):184-91.

21. Crivelli MR, Muhlmann M, Adler I, Cornicelli JC. [Prevalence of oral pathology in children]. Rev Asoc Odontol Argent. 1986 June;74(3):80-2. Spanish.

22. Majorana A, Bardellini E, Flocchini P, Amadori F, Conti G, Campus G. Oral mucosal lesions in children from 0 to 12 years old: ten years' experience. Oral Surg Oral Med Oral Pathol Oral Radiol Endod. 2010 Jul; 110(1):e13-8.

23. Santos BPJ, Bessa CF, Aguiar MCF, Carmo MAVC. Crosssectional study of oral mucosal conditions among a central Amazonian Indian community, Brazil. J Oral Pathol Med. 2004 Jan;33(1):7-12.

24. Bezerra S, Costa I. Oral conditions in children from birth to 5 years: the finding of a children's dental program. J Clin Pediatr Dent. 2000 Fall;25(1):79-81.

25. Shulman JD. Prevalence of oral mucosal lesions in children and youths in the USA. Int J Paediatr Dent. 2005 Mar;15(2):89-97
26. Corrêa MSNP, Villena RS, Frascino SMV. Avaliação clínica das características da cavidade bucal e da ocorrência de anomalias em recém-nascidos. Rev Paul Odontol. 1997 MayJun;19(3):34-40. Portuguese.

27. Santos-Anaya R, Beltrán-Grados G. Moluscos contagioso: presentación como quiste epidérmico / Contagious moluscum: A case as epidermic cyst. Dermatol Peru. 2001 JanJun;11(1):43-5.

28. Bello V, Osorio Díaz Y, Guerra M, Tovar, V. [Molluscum contagiosum: HIV/AIDS opportunistic infection]. Acta Odontol Venez. 2005 [cited Aug 10]; 43(2): 193-7. Avaliable from: http:// www.actaodontologica.com/ediciones/2005/2/molusco_ contagioso_infeccion_oportunista_vih_sida.asp. Spanish.

29. Messner AH, Lalakea L, Aby J, Macmahon J, Bair E. Ankyloglossia: incidence and associated feeding difficulties. Arch Otolaryngol Head Neck Surg. 2000 Jan;126(1):36-9.

30. Zain RB. Classification, epidemiology and aetiology of oral recurrent aphthous ulceration/stomatitis. Annal Dent Univ Malaya. 1999 Jun;6(1):34-7. 